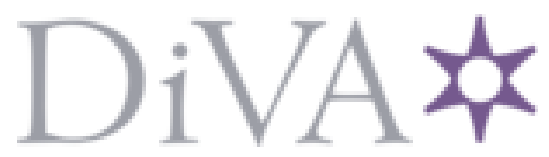

http://www.diva-portal.org

This is the published version of a paper published in Studies in the novel.

Citation for the original published paper (version of record):

Lindhé, A. (2016)

The Paradox of Narrative Empathy and the Form of the Novel, or What George Eliot Knew.

Studies in the novel, 48(1): 19-42

Access to the published version may require subscription.

N.B. When citing this work, cite the original published paper.

Permanent link to this version:

http://urn.kb.se/resolve?urn=urn:nbn:se:umu:diva-118973 


\title{
THE PARADOX OF NARRATIVE EMPATHY AND THE FORM OF THE NOVEL, OR WHAT GEORGE ELIOT KNEW
}

\begin{abstract}
ANNA LINDHÉ
A man falling into dark water seeks a momentary footing even on sliding stones; and Silas, by acting as if he believed in false hopes, warded off the moment of despair.

- George Eliot, Silas Marner (47)

The only wisdom we can hope to acquire / Is the wisdom of humility.

- T. S. Eliot, "East Coker" (II.48-49)
\end{abstract}

It is usually assumed that empathy-the ability to imagine oneself into the inner life of another-is a good thing (Prinz 211). Recent research links empathy with ethical consequences such as "altruism and prosocial behavior, moral development, interpersonal bonding, and improved intergroup relations" (Harrison 256). Empathy has become a ubiquitous concept in areas ranging from politics, law, and business ethics to medical care and education, to name just a few (Coplan 3). The benefits of empathy are presumed to be considerable and the lack of it is often deplored, sometimes being associated with psychopathy and criminality (Harrison 256). Several perspectives, including evolutionary ones, are based on the view that empathy is an evolved faculty, vital to humankind's cooperation and hence survival (Moore and Hallenbeck 471). In other words, empathy is thus often considered to be useful, indispensable, and even morally good. ${ }^{1}$

The notion that the act of reading literature expands our empathy is a popular one. ${ }^{2}$ The idea that reading develops our ability to shift perspectives, and that it enhances our understanding of unknown others, is often heard in academia as well as beyond. Martha Nussbaum believes that the empathy induced by reading literature can have an influence on a person's moral development and even prompt altruistic behavior in the real world, a contention she shares with many other philosophers and with (developmental) 
psychologists (Keen, "Novel Readers" 21). Recently, the psychologists David Kidd and Emanuele Castano published a conspicuous study in Science, submitting that reading (good) fiction improves empathy. Although the outcomes they reported were far from conclusive, the impact on the public debate was massive and bolstered the case for literature as a tool to improve our moral character.

Even so, the idea that empathy, or what is referred to here as narrative empathy - that is, "the sharing of feeling and perspective-taking induced by reading, viewing, hearing, or imagining narratives of another's situation and condition" (Keen, "Narrative Empathy") - has a civilizing effect on our behaviors and attitudes has been challenged within literary studies. That empathy somehow enters into the fictional experience may be a fairly uncontroversial idea. As Fritz Breithaupt puts it, "there would probably be no fiction if we did not have the ability to imagine how it feels to be another or to be in another's situation" (2); but empathy's role in prosocial behavior and altruism has been greatly debated. Although admitting empathy's essential role in reading, Suzanne Keen is critical of the altruism-empathy hypothesis as it relates to fiction. In her influential book Empathy and the Novel (2007), she questions "the contemporary truism that novel reading cultivates empathy that produces good citizens for the world" (xv). According to Keen, there is very little empirical evidence that suggests a clear causal relationship between novel-reading and altruism. In fact, Keen shows that readers empathize in unforeseen ways (Morgan 32) and that altruistic behavior after reading is quite unusual. ${ }^{3}$ The recent anthology Rethinking Empathy through Literature (2014) follows up on some of the questions raised by Keen, addressing the increasing need to problematize the concept of empathy and confront the widespread idea that reading literature generates prosocial behaviour. ${ }^{4}$

This discussion sets out to problematize the empathy-altruism hypothesis as it relates to literature - that is, the assumption that literature makes us better people - by examining a paradox engendered by empathy in the novel. There is a flipside to empathy that has not been sufficiently explored in narrative ethics or in theories of literature and the emotions, a flipside that I would like to formulate as a question: can we credibly argue that reading literature produces ethical effects if empathetic responses to one character occur at the expense of another character in the story world? The presumed empathy that the reader feels with a literary figure may trigger, or even be contingent on, the reader's antipathies or indifference towards another character in the story. As will be demonstrated below, the fact that empathy in literature may be intimately bound up with its opposite - that empathy may presuppose and/or trigger negative feelings towards other literary figures - raises important reservations about the ethical consequences of literature. For if literature creates an understanding of the Other, as submitted by Nussbaum and others, it simultaneously creates an Other - or the Other's Other- - towards whom less favorable feelings may be 
directed, a paradox that complicates the supposed ethical effects of literature and may even short-circuit its ethical efficacy. To put it differently, the empathyaltruism hypothesis, or the idea that "the reader practices being empathic while reading a fictional story"- and that this augments "the empathic skills of the reader" (Bal and Veltkamp 2) - needs to be qualified by the possibility that readers, compelled to do so by narrative strategies, then also practice being "non-empathetic" during the reading experience.

The first part of this essay situates what I call the paradox of narrative empathy within the context of literature and ethics, presenting, above all, Nussbaum's fusion of literature and ethics as well as problematizing her elevation of the realistic nineteenth-century novel (for stimulating caring feelings for others). The second part explores the paradox of narrative empathy in George Eliot's novel Silas Marner (1861). Starting out from two scenes, I examine two rhetorical strategies employed in literature to engage readerly empathy: conflicts between characters and the tension between story and discourse. These fundamental narrative aspects, I argue, orient readers' empathetic responses to one character at the expense of another in ways that reveal that the act of reading literature can never be a straightforward exercise in "fellow-feeling." For while rhetorical strategies elicit readerly empathy, they also serve to inhibit it. In examining the techniques used to guide the reader to assume one ethical perspective on a character rather than another or, in the words of James Phelan, "to respond to the communication in one way (or one set of ways) rather than another" ("Cognitive Narratology" 310), I rely on a rhetorical approach to narrative established by Wayne C. Booth and developed by other critics belonging to the field of narrative ethics, such as Phelan, who also focuses on the intrinsic connection between rhetoric and ethics. ${ }^{5}$

The purpose of the essay is to complicate the relation between literature and ethics by examining the conditions for and consequences of empathetic responses to characters, filling a gap in the field of narrative ethics as well as articulating, with Hammond and Kim, what literary studies can "teach us about empathy" (1). As Hammond and Kim remind us: "while most discussions of literature and empathy outside literary studies do not consider the question of aesthetics, form and style are critical to understanding the production and reception of narratives" (11). The discussion of the ethical effects of narrative empathy as, for example, Martha Nussbaum pursues it does not consider the paradox of empathy that the novel brings out by way of its form. Before we insist on empathy's (and literature's) goodness, we need to attend to the literary strategies used to engage readerly empathy.

Reminding us that "there is still a great deal that we do not know about emotionally evocative narrative techniques" ("Novel Readers" 31), Keen accuses narrative ethics of failing to "confront the potentially negative effects of vicious or Machiavellian applications of narrative empathy"-that is, when we feel empathy with ethically suspicious characters or sadists. She also 
suggests that the time has come to attend to the vexed problem involved "when perspective taking is employed to better understand a victim" ("Readers' Temperament" 297). ${ }^{6}$ It is also time to focus on the dilemma inherent in the fact that at the same time as we feel ourselves into certain characters - as we are involved in imagining certain characters as fully "human"-we also feel ourselves out of others, responding to them with antipathy and/or indifference that blocks our empathy. Using Silas Marner as a case study to explore the paradox of narrative empathy reveals Eliot's apprehension about her own ethical project; ${ }^{7}$ besides, the analysis reveals an unforeseen ethical insight at the heart of the novel which has not previously been attributed to that "charming minor masterpiece" (Leavis 60).

\section{Empathy, Emotions, and Paradoxes}

Empathy is one of those concepts that are notoriously difficult to pin down. As the term has become so widely employed in media, politics, art, medicine, education, and business during the last few decades, its meaning has become diluted and sometimes even contradictory. Actually, despite the fact that empathy has attracted much interest in the fields of philosophy, psychology, and neuroscience, there is "no clear and agreed upon answer to the question of what empathy is" (Coplan qtd. in Hammond and Kim 7). For example, the psychologist C. Daniel Batson, best known for developing the empathyaltruism hypothesis, accounts for no less than eight different, if related, uses of the term ("These Things Called Empathy").

"Empathy" as it is used here denotes the "engagement with the characters that are portrayed in representational works of art" (Coplan and Goldie xxxviii), but the concept - which entered the English language in 1909 as a translation of the German word Einfühlung (Coplan and Goldie xii) — was first employed in aesthetics at the end of the nineteenth and the beginning of the twentieth century to articulate how (art) objects elicit emotions and how spectators feel or project themselves into a work of art, literature included (Cook 78). In the words of Benjamin Morgan: "Empathy was originally a term denoting an unconscious physiological reaction to an object, a reaction that involved either the projection of one's ego into an object or one's physical mimicry of it" (32). Today, however, owing to the "affective turn" and the increased interest in empathy in the humanities and social sciences, empathy has primarily come to denote a "psychological process" (Morgan). According to Morgan, this process is "similar to what would have been called sympathy in the eighteenth and nineteenth centuries," that is, how an individual "can share and understand the feelings of another" (32). ${ }^{8}$

In popular parlance "empathy" and "sympathy" are often used interchangeably, but scholarly discussions often keep the two terms apart. In the following, empathy is used in the sense of "feeling with" other individuals, whereas sympathy is used in the sense of "feeling for" another person's 
suffering (Keen, Empathy 4-5). Denoting a psychological process that captures the entering-into or imagining another's feelings, empathy is used here despite the fact that the term was not yet coined in Eliot's lifetime. ${ }^{9}$ In fact, the words Eliot herself uses to describe her ethical project- "to imagine and to feel the pains and the joys" of unknown fictional others (Haight 3:III) - seem to agree with the contemporary understanding of empathy, that is, the ability to feel with other individuals. ${ }^{10}$

The present-day understanding of empathy as a psychological or cognitiveemotional process (which constitutes the basis of Nussbaum's literary ethics; see below) has, according to Morgan, given rise to the connection between ethics/altruism and literature that Nussbaum and others labor to corroborate. This connection between literature and ethics relies on the Aristotelian view of literature, which implies that it is on account of the stimulation of the emotions that literature affects readers' moral character. Even though the turn to the affects in literary studies and in the humanities in general is recent, the idea that there is a special relation between fiction and the emotions goes back to the ancient Greek philosophers and has given rise to a number of paradoxes (Davies 121). Plato, recognizing fiction's ability to evoke emotions and hence its dangerous irrationality, banished the poet from his republic. To Aristotle, however, this connection was a reason to develop ideas about the effects of tragic representations. ${ }^{11}$ The "paradox of tragedy" raises the question of how we can enjoy watching or reading about "fictional situations which are filled with suffering" (Morreall 95). Another paradox that emerges, particularly in discussions of literature and empathy, is what is commonly referred to as "the paradox of fiction"- or the "paradox of emotional responses to fiction"which problematizes the idea that the emotions prompted by reading fictions are real. ${ }^{12}$

Both these paradoxes have given rise to controversy, particularly in regards to their ethical implications. How can we experience real emotions for characters that we know have no existence in real life? And if these emotions are not real, but rather pseudo-emotions, as philosopher Kendall Walton claims, to what extent can we still assert literature's ethical relevance? If, for example, compassion is shown to be a pseudo-emotion - a fiction - then literature may not be able to develop our moral character at all. Further, how ethical is it to derive pleasure from watching the pain of others even if those others are fictional? And what about the fact that the activity of watching suffering characters takes us away - and takes away - from real human sufferers? As Elaine Scarry reminds us, "it has often been a criticism of literature that the very imaginative labor of picturing others that we ought to expend on real persons on our city streets, or on the other side of the border, instead comes to be lavished on King Lear or on Tess" (104; see also Hogan 285). To spend tears on the suffering of fictive characters does not automatically yield altruistic or helpful behavior in readers. 
The attention that has been devoted to the "paradox of tragedy" and the "paradox of fiction" may explain why scholars have not only overlooked the paradox of narrative empathy (i.e., that we may feel with one character at the expense of another), but also failed to think through what this paradox might mean to the connection between literature and ethics. Another theoretical dilemma that may account for the under-theorization of this paradox is the problem at the heart of the theory of fiction: the degree to which characters may be said to be real. Scholars inclined towards poststructuralist world-views have long asserted that characters cannot be looked upon as "real" people but only as manifestations of language, as signs. This perspective (together with the omnipresence of the "affective fallacy") may explain why literary theory has not attended to the paradox of empathy in literature. For empathy with fictional characters does seem to presuppose that characters are viewed as real people. ${ }^{13}$

For psychologist Jenefer Robinson, readers' belief in the reality of fictional characters is not a problem but a fact. For her, the question of the reality status of characters is irrelevant and the paradox of fiction is a pseudoparadox. Although philosophers, she asserts, make distinctions between "real and imagined" situations, "our psychology does not": "I respond emotionally to whatever seems to have a bearing on my interests and the interests of those to whom I am close (my family, my group, my fellow humans)" (145). ${ }^{14}$ For instance, the reason why we do not attempt to rescue a character in a lifethreatening situation is what she calls "cognitive monitoring," a control mechanism that comes in after "the initial affective appraisal" and enables the reader to suppress any inclination to act on the fictive situation (153). In effect, she argues, "[t]he emotion process is just the same in both the real life and the fictional case" (153). We cannot turn the affective appraisal system off because it is instinctual, and it makes no distinction between an imaginary and a real scenario. If our psychological make-up does not make a distinction between real events (or real people) and fictive ones, then two of the paradoxes that dominate philosophy and literary theory are resolved, or at least they pose no immediate challenge to assertions made about literature's claim on our empathy. But the settling of these dilemmas gives rise to another: the paradox of narrative empathy. For if we do feel genuine emotions towards the people who inhabit literature - and if reading thus expands our empathy, as some empirical research indicates - this also means that we need to take other feelings into consideration when we discuss literature and ethics, including those that spring from the flipside of empathy: antipathy and indifference.

Martha Nussbaum, who gives the emotions - and particularly those induced by novel-reading - a central place in the ethical life, may be said to come close to problematizing the paradox of narrative empathy when she states that literature "cultivate[s] sympathy unevenly, directing our attention to some types of human beings and not to others" (Cultivating Humanity 101). ${ }^{15}$ 
She thus acknowledges literature's potential risks: for example, that stories might well play an essential part in the oppression of people, and that " $[\mathrm{m}]$ any of the stories we tell one another encourage the refusal of compassion, so not even the literary imagination itself is free from blame" (Poetic Justice xvii). However, as with Wayne Booth, whose ethics has influenced her, this is an imbalance that she does not follow through to its logical conclusion. Primarily concerned with promoting the novel as "the good" - to prove that "the novel can be a paradigm of moral activity" (Love's Knowledge 148) - she is less interested in the ways in which empathetic responses to characters engender readerly antipathies and indifference.

In a similar vein, Booth comes close to this dilemma in his book The Rhetoric of Fiction, only to dismiss it as irrelevant:

Even among characters of equal moral, intellectual, or aesthetic worth, all authors inevitably take sides. A given work will be 'about' a character or set of characters. It cannot possibly give equal emphasis to all, regardless of what its author believes about the desirability of fairness. Hamlet is not fair to Claudius... Othello is not fair to Cassio; King Lear is not just to the Duke of Cornwall... But who cares? The novelist who chooses to tell this story cannot at the same time tell that story; in centering our interest, sympathy, or affection on one character, he inevitably excludes from our interest, sympathy, or affection some other character. (78-79)

Commenting on this passage, Alex Woloch suggests that Booth withdraws from the "implication of his insight for fear of wrenching the text away from the author's own intention" (40). In The One vs. the Many: Minor Characters and the Space of the Protagonist in the Novel, Woloch pursues the implication of this narrative logic. He directs our attention to the fact that minor characters, just like the protagonist, also possess a "consciousness" to which the novel could give priority and attention. However, the inner life of these minor characters is "circumscribed" by various means, such as his or her expulsion from the discourse level, in order to elaborate a "singular, central consciousness" $(22,24)$. To Woloch, it is the tension between story and discourse - "between the formed distribution of attention within the discourse and the potential patterning of distribution within the story" (41) - that creates an inevitable imbalance between characters. ${ }^{16}$

Woloch examines this uneven distribution of attention between minor and major characters in the nineteenth-century novel, arguing that the former are sacrificed for the sake of the priority and centrality of the protagonist. Like Woloch, I interrogate "the problem of narrative "fairness"" (41); but rather than analyzing the uneven distribution of attention between minor and major characters, I examine how certain narrative strategies control the reader's distribution of empathy in a manner that challenges the special connection between literature and ethics, here represented by Nussbaum. 


\section{Cultivating Humanity and the Nineteenth-Century Realist Novel}

Martha Nussbaum is one of the most ardent defenders of the empathyaltruism hypothesis as it relates to literature. ${ }^{17}$ Narrative empathy, or what she calls the "literary imagination," which includes shifts in perspective and the ability to empathetically and sympathetically enter into another's inner life, experiences, and conditions, is essential to educating citizens of the world. It is, above all, this aspect of literature that develops readers' ethical competence, according to Nussbaum. For her, literature plays (or should play) a fundamental role in education and in moral and political life, as "[i]t speaks about us, about our lives and choices and emotions, about our social existence and the totality of our connections" (Love's Knowledge 171). By focusing on "the possible" and sensitizing readers to the predicaments of others, thus attuning them to appropriate ethical responses, literature not only improves perception, but also invites readers to "wonder about themselves" (Poetic Justice 5). By way of seeing oneself in the Other and the Other in oneself, as Persson puts it (Varför? 257 ), the reader is trained in a crucial component of a democratic society. Nussbaum thus "defend[s] the literary imagination precisely because it seems to [her] an essential ingredient of an ethical stance that asks us to concern ourselves with the good of other people whose lives are distant from our own" (Poetic Justice xvi). ${ }^{18}$

It is above all the novel that is able to develop the literary imagination, according to Nussbaum. She identifies certain features in the novel that create empathy and compassion, which are essential for good citizenship (Poetic Justice 10). One of these features is the novel's "concrete depiction" of lives which are different from the reader's, but with which the reader is brought into sympathetic contact in the act of reading. Despite being situated in another time and place, the reader shares "general human concerns" with the characters, which is why the reader is able to form "bonds of identification and sympathy" with these figures (7). Nussbaum speaks about a "play back and forth between the general and the concrete" that is "built into the very structure of the genre, in its mode of address to its readers" (8). It is through this readerly activity, Nussbaum suggests, that the novel activates and develops the reader's mode of ethical reasoning.

To Nussbaum it is primarily the realist novel, and especially the nineteenth-century Anglo-American novel, that can play an important role in the cultivation of humanity: the form of the realist novel, she points out, "constructs compassion in readers, positioning them as people who care intensely about the suffering and bad luck of others" (Poetic Justice 66). And indeed, who can argue with the idea that Dickens's novels generally elicit sympathy for the poor or that Eliot brings us into sympathetic contact with a myriad of characters? But if readers are indeed positioned "as people who care intensely about the suffering and bad luck of others," this also means that they are positioned as people who care less about the suffering and bad luck of certain others, often the empathetic target's Other. 
Nussbaum selects Charles Dickens as a writer whose books promote compassion in readers, even though she includes a reservation about him. Reading Dickens, she suggests, "shows us many things about compassion; it does not show us the very particular ways in which our society inhibits our compassion for people of different race, gender, or sexuality" (Poetic Justice 11 , my emphasis). But it is, paradoxically, precisely here, in her emphasis on Dickens's ethical limitations, that a gap in Nussbaum's reasoning is revealed. Because Nussbaum's expectation for the novel is that it will show us how to live, she does not see what the readerly activity that is fundamental to the form of the realist novel actually reveals about processes of othering, or inhibitory processes. David Copperfield (1850) is a prime example of how the readerif positioned as someone who cares about the eponymous hero-participates in readerly processes that nevertheless produce the Other: in this case the character of Uriah Heep. ${ }^{19}$

David Copperfield certainly "does not work to encourage sympathy or identification with Uriah Heep" (McDonald 59), what with Uriah's "cadaverous face" (Dickens 213) and David Copperfield comparing him to a “"fox', 'vulture', 'bat', 'fish', 'eel', 'snail', 'ape', 'baboon"” (McDonald 59). Rather, the novel rather obstructs empathy and compassion for David's enemy. This is how Uriah Heep is portrayed at one point in the narrative:

As I came back, I saw Uriah Heep shutting up the office; and feeling friendly towards everybody, went in and spoke to him, and at parting, gave him my hand. But oh, what a clammy hand his was! as ghostly to the touch as to the sight! I rubbed mine afterwards, to warm it, and to rub his off. (Dickens 219)

How are readers affected by the intense disgust that David heaps on Uriah Heep, marking him as Other, primarily through, as McDonald observes, his physical traits? If readers are invited to feel themselves into David's inner life, to what degree do they also enact those feelings of disgust and blame that are lavished on Uriah Heep? Here is the flipside of empathy: Uriah Heep is a stranger to David, and the more the reader comes to empathize and sympathize with David, the stranger Uriah Heep becomes - so strange, in fact, that he becomes not only the scapegoat in the novel but also of the novel (McDonald 49; Girard). If readers enter into David's inner life, they will also participate in the generation of his Other who becomes unworthy of their care. When $\mathrm{Mr}$ Micawber exclaims that "HEEP, and only HEEP, is the Forger and the Cheat," he "effectively removes blame from the other characters that have been implicated in Uriah's scheming, including Mr Wickfield, David and Micawber himself" (McDonald 48).

That Uriah Heep is "otherized" to the point where he is eventually expelled from the plot may offer some form of emotional satisfaction for the reader, but it also engenders an ethical dilemma: the reader's acceptance and normalization of a dehumanizing process. Can participation in the process of 
passing on blame (so that David and the reader can remain innocent) really be understood to improve our character? Caught up in the web of relations and in the first-person perspective, the reader is naturally excused for not seeing his or her own role in this dehumanizing process; but perhaps we would be well advised to pay attention to such processes, not only because they reveal that empathy plays a more significant part in them than we might think, but also because they may be able to disclose something important about our society (for is it not precisely such processes that contribute to stereotyping and prejudice outside the world of fiction?) and about human psychology: how easily we turn off our feelings. Involving readers in the very processes of othering (blame, scapegoating, dehumanization) that literature is so often assumed to counteract, perhaps the novel has more to do with the "unequal" and "narrow" cultivation of sympathies that Nussbaum identifies in human beings than we would like to admit (Poetic Justice xviii). This is not to censure Dickens (or Eliot, below) but rather, through the exploration of the obverse of empathy and the unexpected effects of the rhetorical strategies used in the novel's appeal to our empathy, to suggest a new ethics of reading.

\section{Tension between Characters: Winners and Losers in the Struggle for Empathy}

Turning to George Eliot to investigate the limits of empathy may come across as a peculiar undertaking. ${ }^{20}$ As is well known, Eliot was one of the principal advocates of the ethical capabilities of literature in Victorian times. ${ }^{21}$ She had a particular ethical purpose with her writing: she wanted readers to enter feelingly and imaginatively into the lives of unknown others. As she wrote in an often-quoted letter to her friend Charles Bray: "[T]he only effect I ardently long to produce by my writings, is that those who read them should be better able to imagine and to feel the pains and the joys of those who differ from themselves in everything but the broad fact of being struggling erring human creatures" (Haight 3:III). Numerous studies have been devoted to delineating Eliot's sympathetic ethics and the ways in which her novels either foster "fellow-feeling" or fail to do so. ${ }^{22}$

Silas Marner may appear as a straightforward exercise in fellow-feeling, considering the stuff on which it is built. The story about Silas, the lonely linen-weaver, who, after having been betrayed by his best friend and accused of a crime that he did not commit, leaves his village, abandons his religious faith, and begins a new life in the little village of Raveloe, later becoming the foster father of a little girl, seems well fitted for Eliot's ethical project. And despite the othering of Silas in the opening pages (Pond 692), it will not be long until this strange but "sane and honest" man (Eliot 9) attracts the reader's sympathies and manages to maintain them to the very end of the novel. However, regardless of the extent to which readers develop their ethical competence by empathizing with Silas, some features of the novel complicate 
its potentially ethical effects. There is a subplot in Silas Marner, centered on the life of Godfrey Cass, whose destiny will become intertwined with Silas's; he is, as the story goes, the unidentified father of the child that Silas takes in. But it is not Godfrey's relation to Silas nor to his daughter that is the subject of the following discussion but his relationship with his brother, Dunstan Cass. These two are pitted against each other in a way that shapes and controls the reader's empathy.

Before the narrator stages the conflict between the two Cass brothers, we are invited to share in the villagers' perception of them. We are to understand that Dunstan is a hopeless character and that the elder brother, Godfrey, although a good-hearted fellow, is not entirely flawless. It is evident that the villagers, and not necessarily the narrator, have taken a stand against Dunstan and favor Godfrey:

people shook their heads at the courses of the second son, Dunstan, commonly called Dunsey Cass, whose taste for swopping and betting might turn out to be a sowing of something worse than wild oats. To be sure, the neighbours said, it was no matter what became of Dunsey - a spiteful jeering fellow, who seemed to enjoy his drink the more when other people went dry-always provided that his doings did not bring trouble on a family like Squire Cass's, with a monument in the church, and tankards older than King George. But it would be a thousand pities if Mr Godfrey, the eldest, a fine open-faced goodnatured young man who was to come into the land some day, should take to going along the same road as his brother, as he had seemed to do of late. If he went on in that way, he would lose Miss Nancy Lammeter... (26)

After this initial village gossip, it is time for readers to acquaint themselves with the two brothers "in person," making up their own minds about them. The reader is invited to observe a scene in which Godfrey is standing in his home "with his hands in his side-pockets and his back to the fire..." (27). Gloomy and composed, he prepares to meet his younger brother who, with a "flushed face" and an "elated bearing," comes onto the stage:

"Well, Master Godfrey, what do you want with me?" said Dunsey, in a mocking tone. "You're my elders and betters, you know; I was obliged to come when you sent for me."

"Why, this is what I want-and just shake yourself sober and listen, will you?" said Godfrey, savagely. (27)

The relation between the two is fraught with tension, and the conflict will intensify. The outward conflict concerns a debt that needs to be paid. Instead of handing over the rent he has recently received from Farmer Fowler to his father, Godfrey has given the money to Dunstan (apparently so he will keep quiet about Godfrey's secret marriage; see below). Godfrey now needs to collect the money, as their father threatens Fowler with distraint (seizure of his property) if he does not pay. But there are other, more covert, sources 
of conflict. Godfrey has surreptitiously married a woman who is his social inferior, and now he wants nothing to do with her. He wishes to marry Miss Nancy Lammeter - an altogether more suitable choice - but if his secret were revealed he would not only lose the chance of marrying Nancy, but also his inheritance. Dunstan, the younger brother who must create his own good fortune, is somehow involved in the making of the marriage and therefore has a hold on Godfrey, which he uses against him. This is one source of conflict between the two brothers, but readers attentive to details will notice another: Dunstan's powerless position vis-à-vis his brother. Dunstan's "jealous hate and his cupidity" (Eliot 34) are left unexplained, but these traits may well be regarded as a reaction to economic and social injustice: Dunstan is neither the eldest nor their father's favorite - that is his other brother, Bob.

If it is obvious that Silas is positioned as deserving of the reader's empathy in the main plot, it is less clear, at least initially, which of the two brothers should earn the reader's empathy. Among the techniques Eliot usually employs to shape her readers' empathy are free indirect discourse and narratorial commentary (Håkansson 9), but the heterodiegetic-extradiegetic narrator does not adopt these techniques here. We are not invited into the inner lives and thoughts of the characters, at least not at first. In addition, the narrator does not intervene in order to guide or influence the reader in one way or another, as is customary for the narratorial instance in Eliot's fiction. Instead, we are immediately drawn into a conversation between the brothers in which neither comes across as wholly good or bad. In fact, neither appears in a particularly flattering light. Instead, Eliot pits two characters against each other and invites the reader to take sides in the conflict that is played out before them.

In his essay in Emotion Review, "The Blocking of Empathy, Narrative Empathy, and a Three-Person Model of Empathy," Fritz Breithaupt introduces an interesting theory. Starting out from the idea that human beings are "hyper empathic," that is, that they "cannot help but empathize with others," he suggests that people are continuously engaged in "mental activities" that help them avoid the risk of loss of self or loss of perspective. In order to protect ourselves from "excess of empathy" that may otherwise have us "constantly and involuntarily adopt others' perspectives," we possess "control mechanism[s]" that block out empathy (2). One of the ways in which humans bypass these "inhibitory tendencies" is by way of side-taking: "Situations that induce sidetaking, meaning observations of conflict, seem to be especially well suited to trigger empathy, that is to bypass empathy's blocking mechanism" (5). And sidetaking usually involves not two but three positions. So, instead of describing empathy as a matter of interaction between two persons (as is usually the case in contemporary theories of empathy, on which Nussbaum relies in her discussion of literature's ethical effects), empathy, according to Breithaupt, is an effect of side-taking in a three-person interaction in which one person observes a situation involving some kind of conflict or tension between two other individuals. 
Breithaupt's argument is of course applicable to the situation in which readers often find themselves while reading literature: as observers of conflicts between literary characters. Conflicts, within as well as between literary figures, drive most stories forward. However, it is often the inner conflict that is emphasized: it is because readers take part in the inner life of a character, in his or her thoughts and feelings, that empathy is elicited in the reader (Keen, Empathy 96; Harrison 261). But the scene between the brothers described above indicates that we need not feel ourselves into a character in order to empathize; it may be enough that the reader's mental readiness to take sides in a conflict is activated. If empathy is activated as a consequence of sidetaking, as Breithaupt seems to say (and not exclusively dependent upon our imagining ourselves into the other's inner life), then it is a process that has ethically ambiguous consequences in relation to fiction-reading, a suggestion that I will consider below.

Breithaupt's empathy model also suggests that when we are able to detect a clear causal connection - "this pain was caused by that person or event"empathy is "generally stronger" than when such a connection is absent (Cook 82). The reader of Silas Marner is quickly led to understand that the object of Godfrey's "expression of hatred" is Dunstan. When Dunstan walks into the room, Godfrey's mood changes drastically: "at the sight of him Godfrey's face parted with some of its gloom to take on the more active expression of hatred" (27). That the reader is invited to establish a reason for Godfrey's negative feelings may very well be the decisive factor in the reader's choice between the two and consequently determine which of them deserves the reader's empathy. If empathy is aroused for Godfrey, this occurs not so much because he is good and Dunstan is bad-Dunstan is not yet the villain, and Godfrey is surely no more deserving of our empathy here than Dunstan — but because we can identify the cause of Godfrey's negative feelings in Dunstan and thus (together with Godfrey) place the blame on Dunstan's shoulders. If we empathize with Godfrey because we are able to identify the guilty party (in Godfrey's eyes) in the conflict - and if it is enough to take a stand against Dunstan in order for us to take Godfrey's part and empathize with him - how ethical is the empathetic experience that favors Godfrey? Does this form of empathy make us better people?

Further, to pass guilt on to Dunstan would activate the reader's empathy with Godfrey, and thereby also block his or her empathy with Dunstan. If Godfrey comes out as the "winner," it is arguable that that happens because the road to empathy with Dunstan is blocked. The reader would pursue an ethical activity by feeling empathy with Godfrey, but would simultaneously participate in an "unethical" activity by blocking empathy towards another who is not fully responsible for the burden of guilt that is placed on his shoulders. Readers may cultivate their ability to empathize with a character, but they would do so by simultaneously passing on blame to another, implicating themselves in 
the creation of the Other's Other. Does literature improve us if the practice of reading trains us in empathy at the same time as it trains us in withholding it? If blame is directed at Dunstan, Godfrey stands out as innocent. Here is another ethical dilemma: is it ethical to bind somebody to guilt who is not entirely to blame and liberate somebody who is not entirely innocent? Godfrey partly has himself to blame, or as the narrator somewhat evasively admits: "He had long known that the delusion was partly due to a trap laid for him by Dunstan..." (34, my emphasis). Do we at this point have the necessary background for withholding our understanding of Dunstan?

Besides, what if readers empathize with Godfrey not because he is seen to deserve it but because Dunstan elicits negative feelings in them, feelings that really appertain to Godfrey? Godfrey's cathartic feelings dominate the scene, as opposed to Dunstan's partly suppressed irritation and jealousy. ${ }^{23}$ Godfrey directs his hatred against his brother: he speaks savagely, bites his lips, clenches his fist, threatens to knock him down, and expresses a desire to throttle him. Do we "hook on" to the mind that dominates the scene with cathartic feelings? To what extent does the siding with Godfrey have to do with the fact that we recognize and come to approve of the negative feelings that are heaped on Dunstan? Do readers side with Godfrey because he promises the release or purgation of negative feelings, whereas Dunstan does not? Does the mobilization of the reader's potentially "negative" feelings provoke antagonism against Dunstan?

These questions partly arise from Breithaupt's empathy model, which regards empathy as a process involving three agents rather than two. The connection between empathy and ethics/altruism represented by Nussbaum builds on a two-person interaction between a reader and a character. Breithaupt's model not only challenges the idea that empathy is an inherently ethical process, but it also has consequences for our understanding of how empathy works in the novel, particularly in situations where readers are invited to witness conflicts between characters. The discussion above shows that tensions between characters may shape readers' emotional responses and control their empathy in unexpected ways. Such tensions lead to doubts about the existence of any straightforward ethical or innocent readings or readers, as empathy is an activity whose consequences are not entirely, or not always, ethically defensible. We would thus be well advised to attend to conflicts between characters and the reader's role in the distribution of empathies before we insist on the inherent goodness of narrative empathy (and of literature).

\section{The Tension between Story and Discourse and the Sacrificial Structure of Narrative}

There is another scene in Silas Marner that disturbs the common notion of empathy as an inevitable ethical process, a scene which manifests the paradox of narrative empathy in a particularly conspicuous manner. In this 
scene, the narratological tension between story and discourse- the most fundamental formal distinction of narrative (Cohn 110) - shapes the reader's ethical commitment to one character at the expense of another. The scene is also important because it directs us to a dilemma at the heart of the novel itself: its sacrificial dimension. Discussed below, the scene focuses our attention on a sacrifice in which the reader unwittingly participates in a way that complicates the ethical effects of literature as well as reveals the novel's central ethical insight.

One day when Silas returns home after an errand in the village, he finds that his beloved gold is missing. Whereas Silas is left in the dark as to who the perpetrator is, the reader knows that it is Dunstan Cass who, after a failed attempt to collect the money he owes his brother, sneaks into Silas's house and accidently comes upon Silas's treasure. He manages to escape with the gold just prior to Silas's return home. But an important piece of information is withheld from the reader here and not revealed until much later. What the reader does not know is that when Dunstan steps out of Silas's cottage - stepping "forward into the darkness" (44), as the book says - he meets a different darkness as well. The step out of the cottage is not just a step into the dark night; it is also a step into death. But it is not until towards the very end of the novel that the reader, together with the characters, is told that Dunstan drowned in the flooded stone pit just outside Silas's cottage. He is not found until sixteen years later, "wedged between two great stones" (184).

Rather than pursuing Dunstan's struggle for his life, however, the story shifts focus to Silas: "When Dunstan Cass turned his back on the cottage, Silas Marner was not more than a hundred yards away from it..." (44). The narrative is now entirely focused on Silas's horrific discovery:

As soon as he was warm he began to think it would be a long while to wait till after supper before he drew out his guineas, and it would be pleasant to see them on the table before him as he ate his unwonted feast. For joy is the best of wine, and Silas's guineas were a golden wine of that sort.

He rose and placed his candle unsuspectingly on the floor near his loom, swept away the sand without noticing any change, and removed the bricks. The sight of the empty hole made his heart leap violently, but the belief that his gold was gone could not come at once- only terror, and the eager effort to put an end to the terror. (47)

The reader is now invited to follow Silas's obsessive search for his money, and the suspicion that his gold is gone forever is described in harrowing terms. The reader is invited to witness another's suffering, to feel with and for this lonely old man whose sole light in life is his shining gold, which has now been taken away from him: "Again he put his trembling hands to his head, and gave a wild ringing scream, the cry of desolation" (48).

At this point, I would like to dwell on a particular comment made by the narrator in order to convey Silas's emotional state as he comes to realize his 
loss. Eliot is well known for her use of narratorial commentary (i.e., when the narrator halts the progress of the narrative to comment on an event or a character in the narrative). This is often done to shape the reader's empathetic response to a character. Below, Eliot employs this for her characteristic narratorial intervention into the story-world to persuade the reader to assume a particular attitude towards the narrated situation: "A man falling into dark water seeks a momentary footing even on sliding stones; and Silas, by acting as if he believed in false hopes, warded off the moment of despair" (47, my emphasis). The image of a man who helplessly falls into water but nevertheless maintains a brief moment of hope as he finds momentary support on sliding stones is brought in to emphasize the predicament that Silas finds himself in, the deadly despair and the concomitant hope that wards off the unbearable truth, thus providing a depth to Silas's experience/emotions that is conducive to reinforcing the reader's empathy with him. ${ }^{24}$ Merging with the other descriptions of Silas's feelings, this framing of Silas's experience may not at first strike the reader as in any way remarkable. But knowing that Dunstan actually falls into water in the dark night and is wedged between stones, the comment provokes a peculiar and unexpected connection: although it obviously describes Silas's predicament, it might as well describe Dunstan's moment of death, which must happen just as Silas is frantically searching for his money.

At the same time that the reader is drawn into Silas's search - on the level of the discourse - another figure is dying by drowning, struggling for his life, on the level of the story. Our empathetic experience with one who loses his money takes us away from another who loses his life. In other words, whereas Silas metaphorically loses his foothold by losing his money, Dunstan Cass literally loses his foothold as he falls into the stone pit and dies, but his suffering is not represented. Empathetic experience with Silas thus has a price, since it occurs at the expense of another character. Dunstan's disappearance from the plot may not be a prerequisite for our empathy and compassion with Silas; after all, Dunstan is a thief, and it is quite likely that we would empathize with Silas even if we were invited to witness Dunstan's death. Nevertheless, Eliot leaves us with an ethical dilemma: as we feel ourselves into one man's predicament - as we humanize one character and bring him to life - another man is dehumanized and sacrificed. The expulsion of Dunstan at the level of discourse withdraws the possibility of extending any kind of attention to him. Responding empathetically and sympathetically to the Other (Silas), readers will thus be prevented from extending anything like fellow-feeling to the empathetic target's Other (Dunstan). The very moment when empathy and sympathy for Silas are elicited in the reader, ethics is, in fact, sacrificed, a circumstance that confirms the impossibility of any straightforward ethical response to the text. ${ }^{25}$

It seems to me that it is precisely this aspect of the reading process that Martha Nussbaum and others have failed to confront. Insisting on the 
novel's power of cultivating superiority, she does not consider the costs or the sacrifices involved in achieving the potentially ennobling virtues of empathy/ sympathy — or what the literary text asks readers to give up, or give into, in order to cultivate their humanity. We may be ignorant of the fact that Dunstan dies a dreadful death as we mourn for Silas's loss, but the structure fundamental to all narratives, the tension between story and discourse, compels the reader to participate in a sacrificial activity. Whether the reader of Silas Marner is aware of this or not is a question that must be left unanswered; whether the author was is a question that will be left open for the time being. ${ }^{26} \mathrm{It}$ is clear, however, that narrative structure is inherently sacrificial, whether we are on the receiving or the sending end.

This brings the discussion to Eliot's use of metaphor. The narratorial commentary discussed here obviously comes in the shape of a metaphor, and, as stated above, it contributes to making Silas come alive to us at the expense of another character. The metaphor employed in this scene thus reminds us that metaphors are hierarchical and require - and engage readers in - a sacrifice of vehicle for the sake of tenor, and that metaphors bring characters to life as much as they dehumanize, creating closeness as much as distance and empathy as much as unresponsiveness. ${ }^{27}$ However, if the metaphor moves readers not only towards Silas's inner state but also towards making that connection to Dunstan, to what is left out of the discourse, then the metaphor encourages readers to assume a double vision. ${ }^{28}$ This double vision — of two, rather than one, fallen men - may prompt ethical inquiries into the relationship between empathy and justice. As we are absorbed in Silas Marner's distress over the loss of his money on the discourse level, we are taken away from Dunstan Cass's distress over the loss of something much more valuable: his life. The double vision thus draws our attention to a potential injustice - or to a disproportionateness - that may violate other ethical principles that readers may have.

Attending to the tension between story and discourse may even grant readers a deeper ethical insight into themselves. The reader's movement between story and discourse may activate his or her ethical reasoning, prompting the emergence of a new ethics of novel-reading that differs from the literary ethics proposed by Nussbaum. ${ }^{29}$ To Nussbaum it is, above all, identification —or the reader's reflective oscillation between him- or herself and the fictional Other - that stimulates the reader's empathy and therefore his or her ethical reflection and behavior. But instead of seeing ourselves in the Other and the Other in ourselves, the double vision proposed here encourages readers to see themselves in the text and their own role in the creation of the Other. Heeding the paradox of narrative empathy - the possibility that empathy may occur simultaneously with the withdrawal of empathy - may increase readers' awareness of their own role and responsibility in the activity of reading. Faced with this ethical dilemma, readers can reach a deeper awareness about 
themselves and others: that all human activities, writing and reading included, involve sacrifices or choices.

At the end of Silas Marner, Dunstan is brought on to the discourse level only to be "sacrificed" yet again. His return brings secrets into the open, establishing relationships as well as securing a sense of closure for the reader. Dunstan thus resurfaces, but he is not resurrected in the shape of a person. The reader cannot respond to him as a real human being - as a "mimetic character," to use one of Phelan's character categories (Narrative 29) - because he returns as a dead body. Dunstan is dismissed from the discourse as a mimetic character only to emerge as a function in the author's narrative design or, in the words of Phelan, as an "artificial construct" (Narrative 29). Dunstan fulfills an important function in the text. He is, to use Woloch's term, the worker: "the flat character [in the nineteenth-century novel] who is reduced to a single functional use within the narrative" (25). If the text had not turned Dunstan into the Other, neither Silas nor Godfrey would have achieved reconciliation. It is because Dunstan steals the gold that Silas is brought into a community of love and the door can be opened for the atoning figure (Eppie); and it is the information about Dunstan's death that prompts Godfrey to reveal his secret to his wife, Nancy Lammeter - whom he has ironically been able to marry owing to the death of his first wife, who appropriately enough disappears from the plotwhereupon he is able to move towards redemption.

Godfrey gains an important insight about himself and his life, but only at the expense of the death of another: "Everything comes to light, Nancy, sooner or later. When God Almighty wills it, our secrets are found out. I've lived with a secret on my mind, but I'll keep it from you no longer. I wouldn't have you know it by somebody else, and not by me-I wouldn't have you find it out after I'm dead. I'll tell you now" (184-85). The reappearance of Dunstan at the end of the story thus brings about reconciliation for Godfrey and relief for Nancy:

"It's Dunstan - my brother Dunstan, that we lost sight of sixteen years ago. We've found him - found his body - his skeleton."

The deep dread Godfrey's look had created in Nancy made her feel these words a relief. She sat in comparative calmness to hear what else he had to tell. He went on:

"The Stone-pit has gone dry suddenly - from the draining, I suppose; and there he lies - has lain for sixteen years, wedged between two great stones." (183-84)

The novel here quickly shifts attention away from Dunstan's dead body towards the reactions of Godfrey and Nancy. The death of a man is thus not the basis for mourning or compassion, neither for the novel's characters nor for its readers; instead, we are encouraged to withhold our pity for Dunstan so that we can give it to Godfrey and Nancy, reminded that literature is able to blunt readers to suffering while evoking compassion. The novel releases both characters and 
readers - and itself-from any responsibility for Dunstan, thereby revealing something essential about literature: while it trains us in responsibility for the Other, it also trains our ability to liberate ourselves from that responsibility.

The community of Raveloe has been purged of its "evil" or immoral element, an event that clears the way for the worthy, albeit flawed, characters to prevail and for virtuous emotions to be released in the reader. But is all always well that ends well? Readers' sense of their own goodness and innocence may be confirmed as they share "the pains and the joys of those who differ from themselves" (Haight 3:III), but the "feeling with" and "feeling for" occur despite - or because of - the fact that they partake in processes that create the Other. Perhaps we need to be careful not to link literature too narrowly to "the good," if empathy, notwithstanding its moral connotations, is intimately bound up with the process of othering. The position that the reader is invited to assume is hence not as innocent as we would perhaps like to believe. Literature, Magnus Persson muses, "knows things about the reader that the reader does not want to know" (Den goda boken 85, my trans.). Maybe literature knows that we are not innocent. And maybe this was what George Eliot knew: that imagining and feeling our way into the one may well entail the sacrifice of another.

Was this realization why Eliot temporarily tempers our empathy with Dorothea in Middlemarch with the now famous line "But why always Dorothea?", so that we can give it to Causabon? The use of authorial intervention to halt the process of empathizing with one character at the expense of another indicates that there are ways to escape the paradox of empathy in literature. Still, the extra-diegetic intervention emphasizes the problem of empathy and alerts us to the role and responsibility of readers and writers in the processes of empathy and othering. It also indicates a misgiving about the use of omniscience, the narrative technique that "many nineteenth-century novelists trusted to foster sympathy in readers" (Greiner, Sympathetic Realism 125). ${ }^{30}$ An exploration of the side effects of the rhetorical techniques used to elicit empathy in Silas Marner - the conflicts between characters and the tension between story and discourse - helps us to see how Eliot's work draws attention to the paradox of narrative empathy in a way that bears out a tendency in Eliot scholarship towards a questioning of "Eliotian sympathy," rather than a total acceptance of it as always a good thing. ${ }^{31}$

Attending to the limits of empathy yields new perspectives on the ethics of reading literature. The paradox of narrative empathy - the cultivation of empathy at the expense of another-that I have pursued in this essay is the paradox at the heart of the novel. Built into the form of the novel, there is a tension that reminds us that we are not innocent. Rather than showing us how to live, the novel shows us how we do live and what we are, and that image is not always flattering. If we continue to insist that literature should create certain feelings and make us better people - that is if we continue to burden the novel 
with the heavy weight of goodness and innocence-we might fail to perceive our own role and responsibility in what we create. In addition, we might fail to listen to the universal story that literature tells us about ourselves and about what constitutes our humanity: the responsibility towards the Other as well as the denial of the Other. There is humility in that knowledge. Perhaps literature is at its most ethical not when it appeals to our empathy and compassion but when it bears witness to - and confronts us with - this paradox of human life. In Silas Marner, often regarded as George Eliot's simplest novel, Eliot uses the form of the novel to explore this human paradox, providing the twenty-firstcentury reader with the means by which to engage with it and conferring the status of experimental writer and moral philosopher on the author herself. ${ }^{32}$

\section{UMEÅ UNIVERSITY}

\section{NOTES}

Acknowledgments: This essay is for Marianne Thormählen, professor of English literature at Lund University, Sweden, whose knowledge of life and literature is always an inspiration. I would also like to thank the anonymous readers for their insightful comments and helpful suggestions for improving the essay, as well as the members of and visitors to the higher research seminar in literary studies at the Department of Culture and Media Studies, Umeå University, Sweden, for their careful reading of the first draft.

${ }^{1}$ There is also a burgeoning inclination towards questioning empathy's goodness in philosophy. See, for example, Prinz. Even evolutionary cognitive scientist Stephen Pinker admits it is a "fickle emotion. It is triggered by cuteness, good looks, kinship, friendship and solidarity. And it is easily shut off or converted to its opposite, schadenfreude, by competition or revenge"; qtd. in Keen, "Novel Readers" (27).

${ }^{2}$ See, for example, Jurecic 10.

${ }^{3}$ In a later essay on narrative empathy and altruism, Keen "follows up on research and theorizing that has been undertaken" in this area since the publication of Empathy and the Novel; see "Novel Readers" (21).

${ }^{4}$ C. Daniel Batson accounts for the complexity of the term "empathy" in "These Things Called Empathy."

${ }^{5}$ James Phelan argues that the ethical judgments we make of characters (narrators and authors) are crucial for our engagement with literature; see Experiencing.

${ }^{6}$ Some research has been carried out here, however. See, for example, Koopman. See also Leake, who identifies a risk with what he calls "easy empathy": "that it feels good to empathize with a victim seen as deserving and in need of empathy" (177).

7 In an interesting essay, Mary-Catherine Harrison uses Elizabeth Gaskell's novel Mary Barton: A Tale of Manchester Life (1848) for a "critical case study in narrative empathy." She shows how this novel proves the "potential ethical consequences of empathizing with fictional characters from outgroups" (258). Kristen Pond reveals Eliot's "unease" about her ethical project, an unease which, she suggests, has not been fully recognized in Eliot studies, arguing that Silas Marner is "Eliot's most provocative experiment in redefining nineteenth-century understandings of the sympathetic act" (691).

${ }^{8}$ See also Keen, Empathy xxii.

9 According to, for example, Williams, Eliot's sympathy is what we today call empathy (45).

${ }_{10}$ According to Hammond and Kim, the best-known definition of empathy is the one popularized by Nussbaum (and Pinker) (7). See, however, Batson in "These Things Called Empathy" for an assemblage of definitions of the term. 
11 Aristotle explains our appreciation of the negative emotions aroused by tragic representations with the term catharsis: we enjoy watching or reading about suffering because we are purged of pity and fear.

12 The paradox of fiction was introduced by Radford and Weston.

13 In David Miall's words: "One problem of empathy with fictional characters...is that it appears to require belief in the reality of the fictional character" (389). Asserting that "belief is... evoked by the prototypical truth of the feelings we experience for characters, not the characters themselves" (390), Miall dodges the problem of readers' belief in the reality of characters at the same time as he neatly solves the paradox of fiction.

${ }^{14}$ However, Martha Nussbaum assumes a similar standpoint on the issue of the authenticity of literary emotions. For a note on this, see Greiner, Sympathetic Realism 2-3.

15 It should be pointed out that Nussbaum's literary ethics is not in any way simplistic. It seems, for example, important to point out that Nussbaum advocates a sympathetic reading of literary texts, albeit one that is checked by a critical attitude towards them.

${ }^{16}$ Or, in Woloch's terms, "disjunctions between the attention the discourse grants certain characters and the attention that they would grant themselves and that the reader might grant them" (41). Story denotes the chronological order of the events in the mind of the reader; discourse denotes the arrangement or "selection" of events in the order in which they appear in the text. See, for example, Cohn, who states that story signifies "the events referred to by the text" and discourse "the way these events are presented" (110-11).

17 The empathy-altruism hypothesis was originally coined by psychologist C. Daniel Batson. See, for example, Altruism in Humans.

${ }^{18}$ It is by way of the emotions - intrinsic to the structure of the novel and present in the reader's responses - that literature "solicits" the reader's attention, according to Nussbaum (Poetic Justice 53). To her, the emotions attached to the reading experience are valuable precisely because of the good actions and attitudes they generate. By acknowledging the pivotal role of the emotions for judgments or reason, Nussbaum breaks with a long Western tradition, which builds on a dichotomous relation between (rational) reason and (dangerous) passion.

19 For an interesting discussion of Dickens's minor characters and the asymmetric structure of the realist novel, see Woloch. At one point in this book, he says: "In all of Dickens's novels, minor characters persistently wrest attention away from any privileged, central figure-but they never succeed in destroying the asymmetric structure that condemns them to minorness" (143).

${ }^{20}$ But as Hammond and Kim point out: "Literary and cultural critics have long challenged the empathy-altruism hypothesis as it pertains to literature, particularly in Victorian studies, where the discourses of compassion, sympathy and charity have long been central objects of inquiry" (11).

21 See, for example, Greiner, "Sympathy Time" 299.

22 See, for example, Greiner, Kornbluch, Albrecht, Sopher. For an overview on the topic of sympathy, see Sopher 2, n1.

23 Ngai speaks about feelings "amoral and noncathartic, offering no satisfactions of virtue, however oblique, nor any therapeutic or purifying release" (6).

${ }^{24}$ Gezari reminds us that Eliot uses metaphors to "define her characters' feelings" (98).

25 For a thought-provoking discussion on reading and responsibility, see Attridge, particularly pages $56-77$.

${ }^{26}$ Was Eliot perhaps aware of what she was doing in this scene? Gillian Beer reminds us that Silas Marner makes us aware of "coincidence, of the haphazard assemblage of circumstances by which things come to be" (127); but although coincidence drives the narrative forward, the metaphor of falling into dark water and sliding on stones to describe Silas's experience as, to repeat, Dunstan dies by drowning in dark water, his body later found wedged between stones, comes across as anything but coincidental.

27 "[F]ully aware of the slippery nature of figurative language," Eliot had an ambivalent attitude to metaphor (see Rignall 248; see also Young). Discussing a particular passage in The Mill on the Floss, Young argues that "Eliot wonders about how metaphor can both represent and fail to represent another mind" (95-96). The use of the metaphor in this scene is a clear example of the simultaneous failure and success of metaphor to represent another mind.

28 Metaphors engage readers in the "process of discovering relationships" (see Gezari 102 and Rignall 248). But the metaphor may also disclose something about Eliot's realism. The image brought in to corroborate our impression of the protagonist is not necessarily derived from the 
external world but from the level of the story (or, rather, the metaphor creates the story). The realistic nineteenth-century novel is often described in terms of a mirror of the external world, but the metaphor discussed above asks us rather to notice the tension between story and discourse, thus making the creative process visible. Rather than necessarily referring or mirroring the external world, the metaphor refers to the writing process, reminding us that the novel is not a mirror of reality and the author does not pretend to be a historian.

${ }^{29}$ The ethics of reading proposed here also differs from the one proposed by the poststructuralist ethicists who are concerned with the novel's ability to train the reader "in the honoring of Otherness" (see Hale, "Fiction as Restriction" 189). Hale suggests that the new ethicists actually have much in common with Nussbaum: "both ethical camps not only take for granted the achievement of alterity as the novel's distinctive generic purpose but also understand it to be accomplished through novelistic form" (see "Aesthetics" 200).

${ }^{30}$ According to Greiner, "[f]orm proves a training ground for sympathetic detachment, guiding readers to take on a variety of perspectives they need not fully inhabit," and Eliot "critiqued a proposition fundamental to the literary realism of her time: that sympathy flows from unimpeded access into other minds rather than resulting from the difficult thinking taking place in the gap that separates them from us" (Sympathetic Realism 139-40). See also, for example, Albrecht.

${ }^{31}$ See note 22 in this essay. In Sympathetic Realism, Greiner puts it well: Although Austen, Dickens, and Eliot "were among those authors eager to render sympathy in art"....they were also...suspicious of the notion that knowing or feeling what others feel inspires ethical behaviour in us" (1).

${ }^{32}$ Newton feels the lack of an "intellectual respect for Eliot as a moral philosopher" among critics and contends that Eliot "deserves to be considered as a moral philosopher in her own right" $(41,5)$.

\section{WORKS CITED}

Albrecht, Thomas. "Sympathy and Telepathy: The Problem of Ethics in George Eliot's 'The Lifted Veil." "ELH 73.2 (2006): 437-63.

Attridge, Derek. Reading and Responsibility: Deconstruction's Traces. Edinburgh: Edinburgh UP, 2010.

Bal, P. Matthijs, and Martijn Veltkamp. "How Does Fiction Reading Influence Empathy? An Experimental Investigation on the Role of Emotional Transportation." PLOS ONE 8.1 (2013): 1-12. Web. 26 Nov. 2014.

Batson, C. Daniel. Altruism in Humans. Oxford: Oxford UP, 2011.

-. "These Things Called Empathy: Eight Related but Distinct Phenomena." The Social Neuroscience of Empathy. Ed. Jean Decety and William Ickes. Cambridge: MIT P, 2011. 3-15.

Beer, Gillian. George Eliot. Brighton: Harvester, 1986.

Booth, Wayne. The Rhetoric of Fiction. 2nd ed. Chicago: U of Chicago P, 1983.

Breithaupt, Fritz. "The Blocking of Empathy, Narrative Empathy, and a Three-Person Model of Empathy." Emotion Review 20.10 (2011): 1-8.

Cohn, Dorrit. The Distinction of Fiction. Baltimore: Johns Hopkins UP, 1999.

Cook, Amy. "For Hecuba or for Hamlet: Rethinking Emotion and Empathy in the Theatre." Journal of Dramatic Theory and Criticism 25.2 (2011): 71-87.

Coplan, Amy, and Peter Goldie. "Introduction." Empathy: Philosophical and Psychological Perspectives. Ed. Coplan and Goldie. Oxford: Oxford UP, 2011. ix-xlvii.

Coplan, Amy. "Understanding Empathy: Its Features and Effects." Empathy: Philosophical and Psychological Perspectives. Ed. Coplan and Peter Goldie. Oxford: Oxford UP, 2011. 3-18.

Davies, David. Aesthetics \& Literature. London: Continuum, 2007.

Dickens, Charles. David Copperfield. 1850. Ed. Nina Burgis. Oxford: Oxford UP, 1999.

Eliot, George. Silas Marner: The Weaver of Raveloe. 1861. London: Vintage, 2010.

Eliot, T. S. Four Quartets. London: Faber and Faber, 2001.

Gezari, Janet K. "The Metaphorical Imagination of George Eliot.” ELH 45.1 (1978): 93-106.

Girard, Réné. The Scapegoat. Trans. Yvonne Freccero. Baltimore: Johns Hopkins UP, 1986. 
Greiner, Rae. Sympathetic Realism in Nineteenth-Century British Fiction. Baltimore: Johns Hopkins UP, 2012.

—. "Sympathy Time: Adam Smith, George Eliot, and the Realist Novel." Narrative 17.3 (2009): 291-311.

Haight, Gordon S., ed. The George Eliot Letters. 9 vols. New Haven: Yale UP, 1954-1978.

Håkansson, Sara. Narratorial Commentary in the Novels of George Eliot. Lund: Lund Studies in English, 2009.

Hale, Dorothy J. "Aesthetics and the New Ethics: Theorizing the Novel in the Twenty-First Century.” 2009. Why Study Literature? Ed. Jan Alber, et al. Aarhus: Aarhus UP, 2011. 195209.

—. "Fiction as Restriction: Self-Binding in New Ethical Theories of the Novel." Narrative 15.2 (2007): 187-206.

Hammond, Meghan Marie, and Sue J. Kim, eds. "Introduction." Rethinking Empathy through Literature. New York: Routledge, 2014. 1-18.

Harrison, Mary-Catherine. "How Narrative Relationships Overcome Empathic Bias: Elizabeth Gaskell's Empathy across Social Difference.” Poetics Today 32.2 (2011): 255-88.

Hogan, Patrick Colm. What Literature Teaches us about Emotion. Cambridge: Cambridge UP, 2011.

Jurecic, Ann. "Empathy and the Critic." College English 74.1 (2011): 10-27.

Keen, Suzanne. Empathy and the Novel. Oxford: Oxford UP, 2007.

—. "Narrative Empathy." The Living Handbook of Narratology. Ed. Peter Hühn, et al. Hamburg: Hamburg UP, 2013. Web.

-. "Novel Readers and the Empathetic Angel of Our Nature." Rethinking Empathy through Literature. Ed. Meghan Marie Hammond and Sue J. Kim. New York: Routledge, 2014. 2133.

—. "Readers' Temperament and Fictional Character." New Literary History 42.2 (2011): 295-314.

Kidd, David Comer, and Emanuele Castano. "Reading Literary Fiction Improves Theory of Mind." Science 342.6156 (2013): 377-80.

Koopman, Emy. "Reading the Suffering of Others: The Ethical Possibilities of 'Empathic Unsettlement."' Journal of Literary Theory 4.2 (2010): 235-52.

Kornbluh, Anna. "The Economic Problem of Sympathy: Parabasis, Interest, and Realist Form in Middlemarch." ELH 77.4 (2010): 941-67.

Leake, Eric. "Humanizing the Inhumane: The Value of Difficult Empathy." Rethinking Empathy through Literature. Ed. Meghan Marie Hammond and Sue J. Kim. New York: Routledge, 2014. 175-85.

Leavis, F. R. The Great Tradition: George Eliot, Henry James, Joseph Conrad. Harmondsworth: Penguin, 1983.

McDonald, Tara. “'Red-Headed Animal': Race, Sexuality and Dickens's Uriah Heep.” Critical Survey 17.2 (2005): 48-62.

Miall, David S. "Feeling from the Perspective of the Empirical Study of Literature." Journal of Literary Theory 1.2 (2008): 377-93.

Moore, Rhonda J., and James Hallenbeck. "Narrative Empathy and How Dealing with Stories Helps: Creating a Space for Empathy in Culturally Diverse Care Settings.” Journal of Pain and Symptom Management 40.3 (2010): 471-76.

Morgan, Benjamin. "Critical Empathy: Vernon Lee's Aesthetics and the Origins of Close Reading." Victorian Studies 55.1 (2012): 31-56.

Morreall, John. "Enjoying Negative Emotions in Fictions." Philosophy and Literature 9.1 (1985): 95-103.

Newton, K. M. Modernizing George Eliot: The Writer as Artist, Intellectual, Proto-Modernist, Cultural Critic. London: Bloomsbury, 2011.

Ngai, Sianne. Ugly Feelings. Cambridge: Harvard UP, 2005.

Nussbaum, Martha C. Cultivating Humanity: A Classical Defense of Reform in Liberal Education. Cambridge: Harvard UP, 1997.

—. Love's Knowledge: Essays on Philosophy and Literature. New York: Oxford UP, 1990.

—. Poetic Justice: The Literary Imagination and Public Life. Boston: Beacon, 1995.

Phelan, James. "Cognitive Narratology, Rhetorical Narratology, and Interpretive Disagreement: A Response to Alan Palmer's analysis of Enduring Love." Style 43.3 (2009): 309-21. 
- Experiencing Fiction: Judgments, Progressions, and the Rhetorical Theory of Narrative. Columbus: Ohio State UP, 2007.

-. Narrative as Rhetoric: Technique, Audiences, Ethics, Ideology. Columbus: Ohio State UP, 1996.

Persson, Magnus. Den goda boken: samtida föreställningar om litteratur och läsning. [The good book: contemporary conceptions of literature and reading] Lund: Studentlitteratur, 2012.

—.Varför läsa litteratur?: om litteraturundervisningen efter den kulturella vändningen. [Why read literature?: the teaching of literature after the cultural turn] Lund: Studentlitteratur, 2007.

Pond, Kristen A. "Bearing Witness in Silas Marner: George Eliot's Experiment in Sympathy." Victorian Literature and Culture 41.4 (2013): 691-709.

Prinz, Jesse J. "Is Empathy Necessary for Morality?" Empathy: Philosophical and Psychological Perspectives. Ed. Amy Coplan and Peter Goldie. Oxford: Oxford UP, 2011. 211-29.

Radford, Colin, and Michael Weston. "How Can we be Moved by the Fate of Anna Karenina?" Proceedings of the Aristotelian Society, Supplementary Volumes 49 (1975): 67-93.

Rignall, John, ed. "Metaphor." Oxford Reader's Companion to George Eliot. Oxford: Oxford UP, 2000.

Robinson, Jenefer. Deeper than Reason: Emotion and its Role in Literature, Music, and Art. Oxford: Clarendon, 2005.

Scarry, Elaine. "The Difficulty of Imagining Other People." For Love of Country?: Debating the Limits of Patriotism. Ed. Martha C. Nussbaum and Joshua Cohen. Boston: Beacon, 1996. 98-110.

Sopher, Robin. "Peripheral Sympathies: Gender, Ethics, and Marginal Characters in the Novels of George Eliot." Diss. McMaster University, 2012.

Walton, Kendall L. Mimesis as Make-Believe: On the Foundations of the Representational Arts. Cambridge: Harvard UP, 1990.

Williams, Wendy S. George Eliot, Poetess. Farnham and Burlington: Ashgate, 2014.

Woloch, Alex. The One vs. the Many: Minor Characters and the Space of the Protagonist in the Novel. Princeton: Princeton UP, 2003.

Young, Kay. Imagining Minds: The Neuro-Aesthetics of Austen, Eliot, and Hardy. Columbus: Ohio State UP, 2010. 